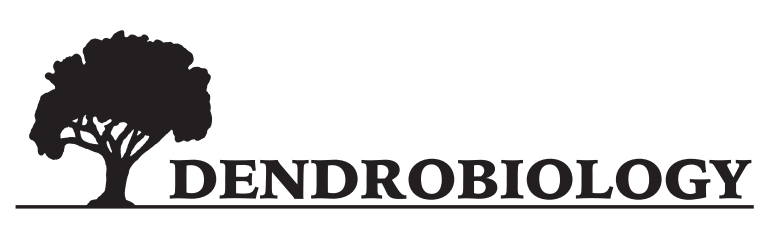

2021, vol. 85, 30-38

https://doi.org/10.12657/denbio.085.004

\author{
Chen Chen, Yuanyuan Cao, Hong Chen, Ming Ni, Fangyuan Yu*
}

\title{
Floral scent compounds and emission patterns of three Styrax species
}

Received: 24 August 2020; Accepted: 27 January 2021

\begin{abstract}
Styrax is a gorgeous species combined with high medicinal and ornamental values, however, information about its floral scents is limited. This study aimed to reveal the floral scent compounds and the dynamic changes in the flowering process of Styrax japonicus, S. grandiflora and S. calvescens. Static headspace solid-phase microextraction coupled with gas chromatography-mass spectrometry was adopted in the present study. The results showed that 24, 22 and 22 volatile compounds were present at three flowering stages, among which linalool, ocimene, $\alpha$-pinene and germacrene $\mathrm{D}$ dominated in different species. Terpenes were the main floral scent compounds in all species, whereas there was considerable relative content of ketones in $S$. japonicus. Among the major terpenes, $\alpha$-pinene, ocimene and myrcene were the common volatiles in these species, while $\beta$-elemene and allo-ocimene were the specific volatiles in $S$. japonicus and $S$. calvescens, respectively. The highest content of terpenes occurred at initial flowering stage in three species. The differences in the type and content of principal compounds contributed to the fragrance diversity among these species. A solid foundation for understanding the complexity of volatile emission could be obtained from our findings, meanwhile, effective utilization of abundant terpenes in flowers of Styrax species should be applied.
\end{abstract}

Keywords: Styrax species, volatile compounds, terpenes, SPME-GC/MS

Addresses: C. Chen, Y. Y. Cao, H. Chen, M. Ni, F. Y. Yu, Collaborative Innovation Centre of Sustainable Forestry in Southern China, College of Forest Science, Nanjing Forestry University, 159 Longpan Road, Nanjing, Jiangsu 210037, China, e-mail: fyyu@njfu.edu.cn; (1) CC https://orcid.org/0000-0003-0026-4025, (1) YC https://orcid.org/0000-0002-2508-4568, (1) HC https://orcid.org/0000-0001-9887-8708,

(1) MN https://orcid.org/0000-0002-4607-2945, (1) FY https://orcid.org/0000-0002-4253-7127

*Corresponding author

Y.Y. Cao and C. Chen contributed equally to this work.

\section{Introduction}

Floral scent is very pleasant to our sensory system and is an important trait to assess the ornamental and economic values of plants (Liu et al., 2014). Floral scent compounds were secondary metabolites that were composed of low molecular volatile substances (Knudsen \& Tollsten, 1993). At present, more than 2000 floral scent compounds have been found from 991 plants, 90 families (Knudsen et al., 2006; Dunkel et al., 2009). Based on Knudsen et al.
(2006), these volatile compounds were divided into benzenoids/phenylpropanoids, aliphatic, terpenoids and nitrogen- and sulfur-containing compounds. Terpenes that contributed to aroma existed in volatile compounds of most plants, such as caryophyllene, (E)- $\beta$-farnesene, $\alpha$-pinene, linalool and so on (Cherri-Martin et al., 2007). Numerous studies have been undertaken with the aim of identifying the volatiles in various plants. Eugenol and isoeugenol were the major volatile compounds in Clarkia breweri (Koeduka et al., 2008); myrcene, limonene, and 
linalool dominated in Hosta plantaginea (Liu et al., 2014); the principal compound in Litsea cubeba was $\alpha$-pinene (Berger, 2007). According to van Schie et al. (2006), the content of phenylethyl alcohol was over $50 \%$ in the study of Rosa hybrida floral scents compounds. Floral volatiles were defined as 'natural compounds', which obtained from higher plants and possessed more values when compared to chemically synthesized products (Berger, 2009; Akacha \& Gargouri, 2015; Vespermann et al., 2017). Linalool has been reported to relieve stress well and be able to alleviate the pain response mediated by a wide range of neurotransmitter system (Peana \& Moretti, 2008). Linalool is also widely used in perfumes, and the consumption of vitamins and many other chemical products, which made from linalool is over 50000 tons each year (Barman et al., 2020). Thus, increase in the content of this compound in floral volatiles would be beneficial. Pinenes are the most abundant components in the essential oils of various plant species. $\alpha$-Pinene and $\beta$-pinene are bicyclic monoterpene hydrocarbons with different fragrance qualities (Kim et al., 2018). It was reported that $\alpha$-pinene was the main aromatic component in Cupressaceae, Pinaceae, as well as Taxodiaceae, furthermore, $\alpha$-pinene odor stimulation was related to stress tolerance, lipid metabolism and health span (Ensaka \& Sakamoto, 2020). Together with color, floral scent is considered to be the main signal attracting insects for ensuring pollination and a defense molecule against attack by herbivorous creatures. The investigation of flower scents is an important field of modern biological research, and the experimental data is helpful to regulate the flower fragrance ( $\mathrm{Li}$ et al., 2006).

To date, solid-phase microextraction (SPME) coupled with gas chromatography-mass spectrometry (GC/MS) is used for analyzing volatile compounds from flowers and other plant materials (Jabalpurwala et al., 2009). Reproducibility, sensitivity and high concentration capability are typical advantages of SPME. This method has been applied to analyze the volatiles of several species, such as Perilla frutescens (Ghimire et al., 2017), Hosta flowers (Liu et al., 2014) and so on.

Styrax, the largest genus in the family Styracaceae, is widely distributed in Asia, North America and southern China (Morawetz, 1991), which comprises about 130 species, such as Styrax japonicus, S. dasyantha, S. grandiflora and S. tonkinensis. Due to its high medicinal, timber, oil and ornamental values, this gorgeous genus has attracted more scientific interest of researchers. Many Styrax species bloom with dense flowers in April or May and quickly enters the blooming stage. Although their fragrance is slight, aromatic compounds in these species have great development potential. As mentioned above, essences extracted from floral volatile compounds are very important raw material in industry and cosmetics. Nonetheless, little information is available regarding the contents and types of volatile compounds in Styrax species. Therefore, it is attractive to ascertain the volatile compounds emitted from flowers of different Styrax species and consequently facilitate the effective methods to enhance the content of useful compounds.

Here, we conducted the experiments to investigate the floral scent compounds and the dynamic changes in three Styrax species at three flowering stages using SPME-GC/MS. We attempted to answer the following questions: (1) Which will floral volatile compounds be emitted from three Styrax species, and which will be the major ones? (2) What are the differences about the contents and types of these volatiles in three species at different flowering stages? Answers we obtained could help establish the appropriate time to harvest flowers and provide a theoretical support for further study of flower aroma in Styrax species.

\section{Materials and methods}

\section{Plant materials}

Plant materials for this study were sampled in planting base of Jiangsu Guoxing Biotechnology Co. Ltd., located in Luhe district, Nanjing $\left(32^{\circ} 54^{\prime} \mathrm{N}\right.$, $118^{\circ} 50^{\prime} \mathrm{E}$ ) in 2019. Six-year-old S. grandiflora, S. calvescens, as well as S. japonicus were chosen for sampling trees in our experiment. These plants grew in natural conditions. In each species, 5 trees with similar height, growth and good condition were selected and tagged. Flower development was divided into three stages, including initial flowering (5\% of the flowers blossomed, and stamens and pistil were exposed), full flowering ( $50 \%$ of the flowers blossomed, stigma was exerted and anthers had bright color) and end flowering ( $95 \%$ of the flowers blossomed and flowers began to fall, stigma, anthers and petals were dry).

\section{Sample collection}

10 flowers from middle part of each tree were collected between 9:00 to 9:20 am at three stages. Then samples were mixed and taken back to the laboratory. $1 \mathrm{~g}$ of flowers was weighed and immediately transferred into a $30 \mathrm{~mL}$ capped vial for collection and identification of floral scent. All experiments were repeated three times.

\section{SPME-GC/MS Analysis}

The SPME equipped with a $65 \mu \mathrm{m}$ PDMS-DVB fiber (Supelco, Bellefonte, PA, USA) was inserted 
into above vial to collect volatile compounds for 30 mins. The collection temperature in our experiment was $50{ }^{\circ} \mathrm{C}$ thus volatile in flowers could be stimulated out better. An empty vial was used as control. After 30 mins, the fiber was inserted into the injection of GC for 3 minutes' sample introduction.

The GC conditions in our experiment were as follows: a GC system (Thermo Fisher Scientific, Waltham, MA, USA) was equipped with a DB-5MS fused silica capillary column $(30 \mathrm{~m} \times 0.25 \mathrm{~mm} \times 0.25$ $\mu \mathrm{m}$, Agilent Technologies, Santa Clara, CA, USA). Helium was used as carrier gas with flow rate of 1 $\mathrm{mL} / \mathrm{min}$. The original temperature was $50{ }^{\circ} \mathrm{C}$ for 2 mins and increasing at $5{ }^{\circ} \mathrm{C}$ per min to $200{ }^{\circ} \mathrm{C}$ with no hold. Then the temperature increased at $10^{\circ} \mathrm{C}$ per min to $220^{\circ} \mathrm{C}$.

The MS conditions in our experiment were as follows: the electron ionization mode of the MS was operated at $70 \mathrm{eV}$, generating a scan range of $45-450$ $\mathrm{amu}$. The ion source and transfer line were $200{ }^{\circ} \mathrm{C}$ and $250^{\circ} \mathrm{C}$, respectively.

\section{Data analysis}

Volatiles were identified by comparing the mass spectra with the National Institute of Standards and Technology (NIST) 12th library and chemistry database (http://pubchem.ncbi.nlm.nih.gov/). The relative content of these compounds was calculated by peak area normalization measurements. Statistics were processed by Excel (Office 2013 Pro Plus, Microsoft Corporation, USA) and values were expressed as mean \pm SD for three replicates. Variance analysis of volatile compounds in flowers of three Styrax species at three flowering stages was performed by SPSS 22.0 (IBM, USA). The significant difference in Duncan's multiple comparisons at the level of 0.05 was established.

\section{Results}

\section{Floral scent compounds and emission patterns of three Styrax species}

Twenty-four volatile compounds were detected at initial flowering stages (Table 1). Among these volatiles, 18, 11 and 12 compounds were identified in S. japonicus, S. grandiflora and S. calvescens, respectively. Linalool (18.61\%), germacrene D (13.26\%), $\alpha$-pinene $(12.04 \%)$ and ocimene $(10.90 \%)$ were top four volatiles in $S$. japonicus and the sum of these four compounds was over $54 \%$. The linalool content in $S$. grandiflora was significantly lower than that in $S$.

Table 1. Floral volatile compounds and relative contents in three Styrax species at initial flowering stage

\begin{tabular}{|c|c|c|c|c|c|}
\hline \multirow{2}{*}{ Type } & \multirow{2}{*}{ RI } & \multirow{2}{*}{ Compounds } & \multicolumn{3}{|c|}{ Relative contents (\%) } \\
\hline & & & S. japonicus & S. grandiflora & S. calvescens \\
\hline \multirow[t]{20}{*}{ Terpenes } & 917 & $\alpha$-pinene & $12.04 \pm 1.29 b$ & $57.08 \pm 6.67 \mathrm{a}$ & $66.46 \pm 9.30 \mathrm{a}$ \\
\hline & 993 & myrcene & $4.88 \pm 1.52$ & $1.94 \pm 1.94$ & $1.42 \pm 0.78$ \\
\hline & 977 & sabinene & $0.09 \pm 0.19 b$ & $8.32 \pm 0.61 \mathrm{a}$ & - \\
\hline & 1001 & phellandrene & - & - & $0.03 \pm 0.37$ \\
\hline & 1012 & $\alpha$-humulene & $1.57 \pm 0.38 \mathrm{a}$ & - & $0.46 \pm 0.16 b$ \\
\hline & 1030 & d-limonene & - & $15.93 \pm 1.43$ & $19.06 \pm 8.07$ \\
\hline & 1032 & ç-murrolene & $4.20 \pm 0.29$ & - & - \\
\hline & 1047 & ocimene & $10.90 \pm 1.28 \mathrm{a}$ & $14.20 \pm 3.64 \mathrm{a}$ & $1.84 \pm 0.68 \mathrm{~b}$ \\
\hline & 1051 & (E)- $\beta$-ocimene & - & $0.12 \pm 0.06$ & - \\
\hline & 1060 & $\gamma$-terpinene & - & - & $2.11 \pm 0.50$ \\
\hline & 1089 & $\alpha$-terpinolene & $2.27 \pm 1.03 \mathrm{ab}$ & $1.26 \pm 0.66 b$ & $5.70 \pm 1.95 \mathrm{a}$ \\
\hline & 1095 & linalool & $18.61 \pm 1.66 \mathrm{a}$ & $0.38 \pm 0.38 b$ & - \\
\hline & 1173 & verbenone & - & $0.42 \pm 0.42$ & - \\
\hline & 1385 & $\beta$-elemene & $2.20 \pm 0.17$ & - & - \\
\hline & 1422 & carophyllene & - & $0.20 \pm 0.20 b$ & $1.55 \pm 0.67 \mathrm{a}$ \\
\hline & 1455 & iso-germacrene $\mathrm{D}$ & $1.38 \pm 0.54$ & - & - \\
\hline & 1469 & aromadendrene & $6.69 \pm 0.38$ & - & - \\
\hline & 1474 & germacrene D & $13.26 \pm 0.87 a$ & - & $0.14 \pm 0.03 b$ \\
\hline & 1508 & $\alpha$-farnesene & $6.09 \pm 1.25 \mathrm{a}$ & - & $0.14 \pm 0.08 b$ \\
\hline & 1511 & gamma-cadinene & $2.40 \pm 0.16$ & - & - \\
\hline Aldehydes & 857 & trans-2-hexenal & $1.16 \pm 0.18$ & - & - \\
\hline \multirow{2}{*}{ Alcohols } & 1526 & trans-nerolidol & $5.29 \pm 1.11 \mathrm{a}$ & - & $1.09 \pm 0.21 b$ \\
\hline & 1556 & elemol & $2.88 \pm 0.62$ & - & - \\
\hline Ketones & 1258 & L-(-)-carvone & $4.09 \pm 0.39 a$ & $0.15 \pm 0.15 b$ & - \\
\hline
\end{tabular}

- indicated that scent compounds were not detected. RI indicated that retention indices of volatiles were calculated using an alkane standard (C8-C30). All data in the table were average of three replicates \pm SD; the letters in the table indicated significant difference in Duncan's multiple comparisons $(\mathrm{P}<0.05)$. 
Table 2. Floral volatile compounds and relative contents in three Styrax species at full flowering stage

\begin{tabular}{|c|c|c|c|c|c|}
\hline \multirow{2}{*}{ Type } & \multirow{2}{*}{ RI } & \multirow{2}{*}{ Compounds } & \multicolumn{3}{|c|}{ Relative contents (\%) } \\
\hline & & & S. japonicus & S. grandiflora & S. calvescens \\
\hline \multirow[t]{18}{*}{ Terpenes } & 917 & $\alpha$-pinene & $11.22 \pm 0.74 b$ & $33.84 \pm 1.48 \mathrm{a}$ & $32.79 \pm 0.29 a$ \\
\hline & 953 & camphene & - & $0.30 \pm 0.01$ & $0.63 \pm 0.06$ \\
\hline & 977 & sabinene & - & $7.03 \pm 0.45$ & $9.88 \pm 0.59$ \\
\hline & 982 & $\beta$-pinene & $0.43 \pm 0.03$ & - & - \\
\hline & 993 & myrcene & $12.58 \pm 1.83 \mathrm{a}$ & $3.32 \pm 0.40 b$ & $2.61 \pm 0.12 b$ \\
\hline & 1001 & phellandrene & - & $0.93 \pm 0.10 b$ & $1.39 \pm 0.03 a$ \\
\hline & 1012 & $\alpha$-humulene & - & $0.16 \pm 0.16$ & - \\
\hline & 1030 & d-limonene & $0.66 \pm 0.05 c$ & $12.16 \pm 1.09 b$ & $29.68 \pm 1.20 \mathrm{a}$ \\
\hline & 1047 & ocimene & $12.14 \pm 1.25 b$ & $21.69 \pm 1.23 \mathrm{a}$ & $4.79 \pm 0.91 c$ \\
\hline & 1051 & (E)- $\beta$-ocimene & $0.31 \pm 0.04$ & $0.29 \pm 0.04$ & - \\
\hline & 1060 & $\gamma$-terpinene & - & - & $3.63 \pm 0.12$ \\
\hline & 1089 & $\alpha$-terpinolene & - & $2.06 \pm 0.28 b$ & $8.70 \pm 0.12 \mathrm{a}$ \\
\hline & 1095 & linalool & $11.67 \pm 1.15 \mathrm{a}$ & $5.70 \pm 3.86 b$ & - \\
\hline & 1173 & verbenone & - & $1.74 \pm 0.67 \mathrm{a}$ & $0.11 \pm 0.02 b$ \\
\hline & 1422 & carophyllene & - & $0.08 \pm 0.08$ & - \\
\hline & 1469 & aromadendrene & $4.24 \pm 0.29$ & - & - \\
\hline & 1474 & germacrene D & $23.97 \pm 0.57$ & - & - \\
\hline & 1508 & $\alpha$-farnesene & - & $0.03 \pm 0.03$ & $0.07 \pm 0.07$ \\
\hline \multirow[t]{2}{*}{ Ketones } & 1189 & $(+)$-dihydrocarvone & $1.10 \pm 0.23$ & - & $0.52 \pm 0.06$ \\
\hline & 1258 & L-(-)-carvone & $11.74 \pm 0.68 \mathrm{a}$ & $1.22 \pm 0.26 c$ & $5.20 \pm 1.21 b$ \\
\hline Alkanes & 1428 & $\begin{array}{l}\text { Tricyclo[4.4.0.02,7]decane,1-methyl-3-methylene- } \\
\text {-8-(1-methylethyl)-, (1R,2S,6S,7S,8S)-rel- }\end{array}$ & $7.41 \pm 0.57$ & - & - \\
\hline Alcohols & 1556 & elemol & $2.53 \pm 0.16$ & - & - \\
\hline
\end{tabular}

- indicated that scent compounds were not detected. RI indicated that retention indices of volatiles were calculated using an alkane standard (C8-C30). All data in the table were average of three replicates \pm SD; the letters in the table indicated significant difference in Duncan's multiple comparisons $(\mathrm{P}<0.05)$.

Table 3. Floral volatile compounds and relative contents in three Styrax species at end flowering stage

\begin{tabular}{|c|c|c|c|c|c|}
\hline \multirow{2}{*}{ Type } & \multirow{2}{*}{ RI } & \multirow{2}{*}{ Compounds } & \multicolumn{3}{|c|}{ Relative contents (\%) } \\
\hline & & & S. japonicus & S. grandiflora & S. calvescens \\
\hline \multirow[t]{19}{*}{ Terpenes } & 917 & $\alpha$-pinene & $18.44 \pm 1.80 \mathrm{~b}$ & $41.44 \pm 6.31 \mathrm{a}$ & $35.04 \pm 0.44 a$ \\
\hline & 977 & sabinene & - & $2.57 \pm 0.40 b$ & $9.18 \pm 0.24 a$ \\
\hline & 982 & $\beta$-pinene & $0.46 \pm 0.24$ & - & - \\
\hline & 993 & myrcene & $4.70 \pm 0.79 a$ & $1.39 \pm 0.70 b$ & $1.79 \pm 0.05 b$ \\
\hline & 1001 & phellandrene & - & - & $1.17 \pm 0.04$ \\
\hline & 1030 & d-limonene & $0.72 \pm 0.05 c$ & $5.43 \pm 0.55 b$ & $24.01 \pm 0.19 \mathrm{a}$ \\
\hline & 1032 & ç-murrolene & $1.59 \pm 0.06$ & - & - \\
\hline & 1047 & ocimene & $4.07 \pm 2.70 b$ & $27.27 \pm 4.11 \mathrm{a}$ & $5.47 \pm 0.60 \mathrm{~b}$ \\
\hline & 1051 & (E)- $\beta$-ocimene & $0.31 \pm 0.17$ & - & - \\
\hline & 1060 & $\gamma$-terpinene & - & $0.36 \pm 0.18 b$ & $3.61 \pm 0.04 a$ \\
\hline & 1089 & $\alpha$-terpinolene & - & $1.47 \pm 0.11 \mathrm{~b}$ & $8.85 \pm 0.30 \mathrm{a}$ \\
\hline & 1095 & linalool & $17.31 \pm 0.37$ & $16.02 \pm 8.98$ & - \\
\hline & 1138 & allo-ocimene & - & - & $0.13 \pm 0.07$ \\
\hline & 1173 & verbenone & - & $1.41 \pm 0.83 a$ & $0.18 \pm 0.01 b$ \\
\hline & 1380 & $\beta$-bourbonene & $0.56 \pm 0.10$ & - & - \\
\hline & 1385 & $\beta$-elemene & $2.48 \pm 0.17$ & - & - \\
\hline & 1469 & aromadendrene & $4.79 \pm 0.24$ & - & - \\
\hline & 1474 & germacrene D & $26.68 \pm 1.04$ & - & - \\
\hline & 1508 & $\alpha$-farnesene & - & $1.16 \pm 0.16 \mathrm{a}$ & $0.10 \pm 0.02 b$ \\
\hline Esters & 1442 & isopentyl benzoate & - & $1.49 \pm 0.25$ & - \\
\hline \multirow[t]{2}{*}{ Ketones } & 1189 & $(+)$-dihydrocarvone & $2.68 \pm 0.15 \mathrm{a}$ & - & $1.23 \pm 0.13 b$ \\
\hline & 1258 & L-(-)-carvone & $15.21 \pm 1.49 \mathrm{a}$ & - & $8.95 \pm 0.78 b$ \\
\hline
\end{tabular}

- indicated that scent compounds were not detected. RI indicated that retention indices of volatiles were calculated using an alkane standard (C8-C30). All data in the table were average of three replicates \pm SD; the letters in the table indicated significant difference in Duncan's multiple comparisons $(\mathrm{P}<0.05)$. 
japonicus, but the $\alpha$-pinene content in S. grandiflora and $S$. calvescens was significantly higher in comparison with S. japonicus. One aldehyde, two alcohols and one ketone were detected in all species at this stage. Thus, it was concluded that both the type and content of terpenes were dominate floral scent compound and the relative content of terpenes was estimated at $86.58-99.85 \%$ of the detected compounds.

Twenty-two volatile compounds were detected at full flowering stages (Table 2), among which $\alpha$-pinene, myrcene, d-limonene, ocimene and L-(-)-carvone were common volatiles in three species. As described above, terpenes were also primary compounds in these species, such as $\alpha$-pinene, d-limonene, ocimene and linalool. Germacrene D (23.97\%) was the most and the unique compound in S. japonicus. Although carophyllene and $\alpha$-humulene only existed in S. grandiflora, their contents were extremely low. S. calvescens had the highest d-limonene, which was significantly higher than that in S. japonicus and S. grandiflora. Except terpenes, the content of ketones and alkanes were relative higher than that of other classifications. Elemol was the only alcohol identified in S. japonicus.

Twenty-two volatile compounds were detected at end flowering stages (Table 3). Germacrene D, $\alpha$-pinene and linalool were the main volatile compounds in S. japonicus flowers, nonetheless, $\alpha$-pinene and ocimene dominated in S. grandiflora flowers. With respect to $S$. calvescens, $\alpha$-pinene, d-limonene and sabinene were top three compounds. So $\alpha$-pinene was the common major volatile in these species with the average content of $31.64 \%$. Ocimene content in $S$. grandiflora was significantly higher than that in other two species. Only 1 ester (isopentyl benzoate ) was found in S. grandiflora and 2 ketones ((+)-dihydrocarvone and L-(-)-carvone) were present in S. japonicus and S. calvescens.

\section{Differences of major terpenes at three flowering stages}

The floral scent compounds were classified into terpenes, esters, ketones, alkanes, alcohols and aldehydes in our study. Obviously, the content of terpenes dominated over the other compounds because their level was estimated at $77.22-99.85 \%$ of all identified volatiles (Fig. 1). Terpenes content exhibited a 'decreasing-increasing' trend in S. japonicus, while terpenes content decreased continuously with the development of S. grandiflora and S. calvescens flowers. It could be easily observed that the average content of terpenes in S. grandiflora was the highest when compared to S. japonicus and S. calvescens. The major terpenes in $S$. grandiflora were $\alpha$-pinene and ocimene. Moreover, obtained results indicated that $\alpha$-pinene content decreased first and then increased,

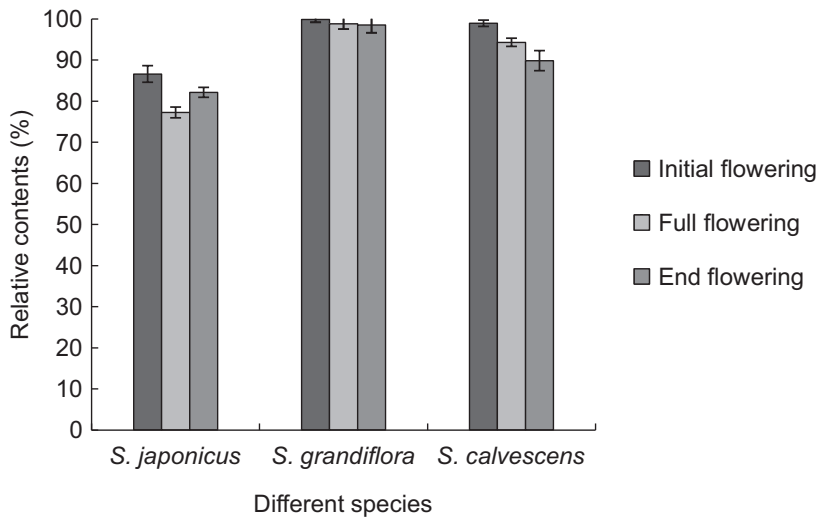

Fig. 1. Terpenes content in three Styrax species at different flowering stages. Results were average of three replicates \pm SD

whereas ocimene content increased gradually. At initial flowering stage, germacrene-d and linalool were the main terpenes in S. japonicus with the contents of $13.26 \%$ and $18.61 \%$, respectively. Their contents still remained at a relative high level along with the development of flowers. $\alpha$-Pinene content in S. calvescens flowers declined sharply from initial flowering stage to end flowering stage. Besides, d-limonene was another main terpene in $S$. calvescens, and its content changed with a single peak curve.

\section{Discussion}

\section{Release patterns of volatile compounds in flowers at three flowering stages}

Plant volatiles are secondary metabolites that emitted from flowers, leaves, fruits and roots of plants (Knudsen et al., 1993). Floral scent compounds play a crucial role in several eco-physiological process and exhibit very complex dynamic changes during flower development (Raguso, 2008; Hosni et al., 2011). The floral scent compounds released by $S$. japonicus, S. grandiflora and S. calvescens at initial flowering, full flowering and end flowering stages were analyzed. Although S. japonicus, S. grandiflora and S. calvescens belong to one genus, significant differences between the types and the contents of volatile compounds in these species occurred. The possible reason behind this was the differences of circadian rhythms in tree species or the differences of characteristics of these compounds. Twenty-four, twenty-two and twenty-two compounds were identified in three Styrax species at three flowering stages, and $\alpha$-pinene, ocimene and myrcene were common volatiles. The total content of terpenes in S. japonicus revealed a ' $\mathrm{V}$ ' trend, which was in agreement with the research conducted by Fan et al. (2019). However, terpenes content descended continuously in S. grandiflora and S. calvescens. Terpenes have 
strong fragrance, so it is reasonable to harvest flowers when terpenes content is more abundant (Shang et al., 2013). To extract beneficial constituents and maximize the ornamental values in $S$. japonicus, $S$. grandiflora and S. calvescens, we advise to harvest their flowers at initial flowering stage.

\section{Comparison of major volatile compounds in flowers}

Flower aroma is indispensable to augment the value of flowers and volatile compounds emitted from flowers were helpful in quality control of oil (Marcos et al., 2002) and effective in anti-inflammatory activity (Tosun et al., 2014). In addition, volatile compounds were involved in defense mechanisms against abiotic and biotic factors in plants (Ramya et al., 2017). As we all know, different plant flowers contain various volatile compounds, among which different proportions may affect each other. One scent could consist of several particular compounds (Laing et al., 1994; Bult et al., 2002). In the present study, germacrene-d and linalool were two major compounds in S. japonicus flowers. However, the results presented here were not completely in agreement with our previous study that germacrene-d, $\alpha$-pinene and ocimene dominated in S. japonicus flowers (Cao et al., 2019). The harvesting hours or stages and various methods of emissions collection led to these differences (Ayanoglu et al., 2005). Meanwhile, major volatiles from $S$. tonkinensis flowers, another species from Styrax, were 1,3,6-octatriene,3,7-dimethyl-, (Z)- and $1 S$ - $\alpha$-pinene (Xu \& Yu, 2015), which were significantly different from compounds identified in Styrax species we detected. The floral scent compositions in Symplocos decora, S. botryantha and S. paniculata were detected, and the results showed that the main compounds in $S$. decora were lilac alcohol isomers, lilac aldehyde isomers and 1-verbenone. In S. botryantha, caryophyllene and 2-ethyl-butanal were the main compounds. Anisaldehyde was the main compound in S. paniculata. The relative contents of these compounds were significantly different (Fu et al., 2016). They concluded that fragrance distinction between these species was due to the dissimilarity in main compounds and their relative contents. Similar implications have also been reported in floral components of different lilac varieties (Li et al., 2006).

\section{Multipurpose linalool and $\alpha$-pinene in flowers}

Terpenes possess very high potential in plant defense mechanisms, as well as strong antioxidant activity (Loreto \& Velikova, 2001). They have been widely used in commercial industries for many different purposes and as natural flavor additives in food. Moreover, terpenes could help prevent cancer, fungal, and enhance skin penetration (Xu \& Yu, 2015). Obtained results confirmed the hypothesis that terpenes contributed to the aroma of most plants. The content of terpenes released from flowers of three Styrax species always remained at a high level at three flowering stages and the major emissions were linalool, $\alpha$-pinene and so on. Linalool, which had a sweet and lemony aroma, was the major compound in S. japonicus and S. grandiflora, and it was also a vital compound in Lippia adoensis (Elakovich \& Oguntimein, 1987). Linalool attracts pollinators and herbivores (Pragadheesh et al., 2017) and is an important intermediate in the synthesis of vitamin $\mathrm{E}$, vitamin $\mathrm{A}$ and ionones (Aprotosoaie et al., 2014). The market of food additives expanded rapidly, among which the flavor and fragrance industries accounted for $31 \%$ (Thomas, 2014). It was indicated that over 8000 tons of linalool was consumed in flavor and fragrance compositions every year (Schwab et al., 2008). Therefore, the studied species could be new sources for linalool extraction. $\alpha$-Pinene was the common compound in three species and present at all flowering stages with high content. Hence, we assumed that $\alpha$-pinene might be the most important floral volatile compound in Styrax species. Similarly, $\alpha$-pinene was the main component in Diplazium esculentum (Essien et al., 2019). The prominent value of $\alpha$-pinene was intensively on pharmacology. $\alpha$-Pinene could cooperate with paclitaxel to accelerate the apoptosis of tumor cells (Zhang et al., 2015). The biological activity of Candida albicans was inhibited by $\alpha$-pinene due to its good bacteriostatic action (Pichette et al., 2006). It was clear that three Styrax species had potential development values of $\alpha$-pinene, so new processes and methods to obtain this excellent compound were in demand. In light of above information, we could perform effective experiments to increase the contents of $\alpha$-pinene and linalool. The 24 -h photoperiod enhanced the biosynthesis of linalool in Lippia alba, possibly due to reduced geraniol synthesis (Castro et al., 2019). Ethylene decreased the linalool content in Lathyrus odoratus (Sexton et al., 2005), whereas silver thiosulfate increased the linalool content in Osmanthus fragrans (Zou et al., 2017). In a word, the valid ways to optimize the floral volatiles demand large research.

\section{Conclusion}

In the present study, we elaborated the floral scent compounds and the dynamic changes in flowers of three Styrax species at different flowering stages. Twenty-four, twenty-two and twenty-two volatile 
compounds were identified in these species at initial flowering, full flowering and end flowering stages, respectively, and the major terpenes were ocimene, myrcene, germacrene-d, $\alpha$-pinene and linalool. Enhancement of these terpenes content may improve floral fragrance, thus helping add the production and ornamental values in flowers. Additionally, the diurnal change of volatile compounds, the appropriate methods for emissions collection and the significance of the plant-pollinator interactions require further study.

\section{Acknowledgements}

This work was supported by Joint Research Project Based on Cooperative Program for Bachelor of Science in Forestry by Nanjing Forestry University and University of British Columbia, A Project Funded by the Priority Academic Program Development of Jiangsu Higher Education Institutions (PAPD) and Postgraduate Research \& Practice Innovation Program of Jiangsu Province (SJKY19_0882).

\section{References}

Akacha NB \& Gargouri M (2015) Microbial and enzymatic technologies used for the production of natural aroma compounds: synthesis, recovery modeling, and bioprocesses. Food and Bioproducts Processing 94: 675-706. doi:10.1016/j. fbp.2014.09.011

Aprotosoaie AC, Hăncianu M, Costache II \& Miron A (2014) Linalool: a review on a key odorant molecule with valuable biological properties. Flavour and Fragrance Journal 29: 193-219. doi:10.1002/ ffj. 3197

Ayanoglu F, Arslan M \& Hatay A (2005) Effects of harvesting stages, harvesting hours and drying methods on essential oil content of lemon balm grown in Eastern Mediterranean. International Journal of Botany 1: 138-142. doi:org/10.3923/ ijb.2005.138.142

Barman M, Kotamreddy JNR, Agarwal A \& Mitra A (2020) Enhanced emission of linalool from floral scent volatile bouquet in Jasminum auriculatum variants developed via gamma irradiation. Industrial Crops and Products 152: 112545. doi:10.1016/j. indcrop.2020.112545

Berger RG (2007) Flavours and fragrances: chemistry, bioprocessing and sustainnability. Springer-Verlag, Berlin, Germany.

Berger RG (2009) Biotechnology of flavours-the next generation. Biotechnology Letters 31: 1651-1659. doi:10.1007/s10529-009-0083-5

Bult JHF, Schifferstein HNJ, Roozen JP, Dalmau Boronat E, Voragen AGJ \& Kroeze JHA (2002) Sen- sory evaluation of character impact components in an apple model mixture. Chemical Senses 27: 485-494.

Cao YY, Jia FF, Wu QK, Chen C, Gao ZZ \& Yu FY (2019) Analysis of volatile compounds in different flowering stages in six species of Styrax spp. Journal of Nanjing Forestry University (Natural Sciences Edition) 43: 48-56.

Castro KM, Batista DS, Fortini EA, Silva TD, Sousa Felipe SH, Mendes Fernandes A, de Jesus Sousa RM, de Queiroz Nascimento LS, Rabelo Campos V, Grazul RM, Viccini LF \& Otoni WC (2019) Photoperiod modulates growth, morphoanatomy, and linalool content in Lippia alba L. (Verbenaceae) cultured in vitro. Plant Cell, Tissue and Organ Culture 139: 139-153. doi:10.1007/s11240-01901672-w

Cherri-Martin M, Jullien F, Heizmann P \& Baudino S (2007) Fragrance heritability in hybrid tea roses. Scientia Horticulturae 113: 177-181. doi:10.1016/j.scienta.2007.03.002

Dunkel M, Schmidt U, Struck S, Berger L, Gruning BA, Hossbach J, Jaeger IS, Effmert U, Piechulla B, Eriksson R, Knudsen JT \& Preissner R (2009) Super scent-a database of flavors and scents. Nucleic Acids Research 37: 291-294. doi:10.1093/ nar/gkn695

Elakovich SD \& Oguntimein BO (1987) The essential oil of Lippia adoensis leaves and flowers. Journal of Natural Products 50: 503-506. doi:10.1021/ np50051a029

Ensaka N \& Sakamoto K (2020) $\alpha$-Pinene odor exposure enhances heat stress tolerance through Daf-16 in Caenorhabditis elegans. Biochemical and Biophysical Research Communications 528: 726731. doi:10.1016/j.bbrc.2020.05.134

Essien EE, Ascrizzi R \& Flamini G (2019) Characterization of volatile compounds of Diplazium esculentum. Chemistry of Natural Compounds 55: 958-959. doi:10.1007/s10600-019-02860-y

Fan JJ, Zhang WX, Zhang DL, Wang GB \& Cao FL (2019) Flowering stage and daytime affect scent emission of Malus ioensis "Prairie Rose". Molecules 24: 2356. doi:10.3390/molecules24132356

Fu JX, Hou D, Wang YG, Zhang C, Bao ZY \& Zhao HB (2016) Floral scent composition and emission patterns of three Symplocos species. Journal of Essential Oil Bearing Plants 19: 1873-1887. doi:10. 1080/0972060X.2016.1257369

Ghimire BK, Yoo JH, Yu CY \& Chung IM (2017) GC-MS analysis of volatile compounds of Perilla frutescens Britton var. Japonica accessions: Morphological and seasonal variability. Asian $\mathrm{Pa}-$ cific Journal of Tropical Medicine 10: 643-651. doi:10.1016/j.apjtm.2017.07.004

Hosni K, Zahed N, Chrif R, Brahim NB, Kallel M \& Sebei H (2011) Volatile oil constituents of Rosa 
canina L.: Differences related to development stages and floral organs. Plant Biosystems 145: 627634. doi:10.1080/11263504.2011.586378

Jabalpurwala FA, Smoot JM \& Rouseff RL (2009) A comparison of citrus blossom volatiles. Phytochemistry 70: 1428-1434. doi:10.1016/j.phytochem.2009.07.031

Kim M, Sowndhararajan K, Park SJ \& Kim S (2018) Effect of inhalation of isomers, $(+)$ - $\alpha$-pinene and $(+)$ - $\beta$-pinene on human electroencephalographic activity according to gender difference. European Journal of Integrative Medicine 17: 33-39. doi:10.1016/j.eujim.2017.11.005

Knudsen JT, Eriksson R \& Gershenzon J (2006) Diversity and distribution of floral scent. Botanical Review 72: 1-120.

Knudsen JT \& Tollsten L (1993) Trends in floral scent chemistry in pollination syndromes: Floral scent composition in moth-pollinated taxa. Botanical Journal of the Linnean Society 113: 263-284. doi:10.1111/j.1095-8339.1993.tb00340.x

Knudsen JT, Tollsten L \& Bergström LG (1993) Floral scents - a checklist of volatile compounds isolated by head-space techniques. Phytochemistry 33: 253-280. doi:10.1016/0031-9422(93)85502-I

Koeduka T, Louie GV, Orlova I, Kish CM, Ibdah M, Wilkerson CG, Bowman ME, Baiga TJ, Noel JP, Dudareva N \& Pichersky E (2008) The multiple phenylpropene synthases in both Clarkia breweri and Petunia hybrida represent two distinct protein lineages. Plant Cell 54: 362-374. doi:10.1111/ j.1365-313X.2008.03412.x

Laing DG, Eddy A, Francis GW \& Stephens L (1994) Evidence for the temporal processing of odor mixtures in humans. Brain Research 651: 317-328. doi:10.1016/0006-8993(94)90712-9

Li ZG, Lee MR \& Shen DL (2006) Analysis of volatile compounds emitted from fresh Syringa oblata flowers in different florescence by headspace solid-phase microextraction-gas chromatography-mass spectrometry. Analytica Chimica Acta 576: 43-49. doi:10.1016/j.aca.2006.01.074

Liu Q, Sun GF, Wang S, Lin Q, Zhang J \& Li X (2014) Analysis of the variation in scent components of Hosta flowers by HS-SPME and GC-MS. Scientia Horticulturae 175: 57-67. doi:10.1016/j.scienta.2014.06.001

Loreto F \& Velikova V (2001) Isoprene produced by leaves protects the photosynthetic apparatus against ozone damage, quenches ozone products, and reduces lipid peroxidation of cellular membranes. Plant Physiology 127: 1781-1787. doi:10.1104/pp.010497

Marcos LI, Pérez PJL, Fernández LME, Garcia PC \& Moreno CB (2002) Detection of adulterants in olive oil by headspace-mass spectrometry. Journal of Chromatography A 945: 221-230. doi:10.1016/ S0021-9673(01)01502-3

Morawetz W (1991) The karyology of some neotropical Styracaceae. Plant Systematics and Evolution 177: 111-115. doi:10.1007/BF00937831

Peana AT \& Moretti MDL (2008) Linalool in essential plant oils: pharmacological effects: Botanical medicine in clinical practice (ed. by VR Reddy \& RR Watson) CAB International, England, pp. 716-724.

Pichette A, Larouche PL, Lebrun M \& Legault J (2006) Composition and antibacterial activity of Abies balsamea essential oil. Phytotherapy Research 20: 371-373.

Pragadheesh VS, Chanotiya CS, Rastogi S \& Shasany AK (2017) Scent from Jasminum grandiflorum flowers: Investigation of the change in linalool enantiomers at various development stages using chemical and molecular methods. Phytochemistry 140: 83-94. doi:10.1016/j.phytochem.2017.04.018

Raguso RA (2008) Wake up and smell the roses: the ecology and evolution of floral scent. Annual Review of Ecology Evolution and Systematics 39: 549-569. doi:10.1146/annurev.ecolsys.38.091206.095601

Ramya M, Kwon OK, An HR, Park PM, Baek YS \& Park PH (2017) Floral scent: Regulation and role of MYB transcription factors. Phytochemistry Letters 19: 114-120.

van Schie CCN, Haring MA \& Schuurink RC (2006) Regulation of terpenoid and benzenoid production in flowers. Current Opinion in Plant Biology 9: 203-208. doi:10.1016/j.pbi.2006.01.001

Schwab W, Davidovich-Rikanati R \& Lewinsohn E (2008) Biosynthesis of plant-derived flavor compounds. Plant Journal 54: 712-732.

Sexton R, Stopford AP, Moodie WT \& Porter AEA (2005) Aroma production from cut sweet pea flowers (Lathyrus odoratus): the role of ethylene. Physiologia Plantarum 124: 381-389. doi:10.1111/j.1399-3054.2005.00498.X

Shang JY, Tian SF, Zhu ZQ, Li SH, Ji X \& Gao Y (2013) Effects of harvesting time on fruit quality and aromatic compounds in Muscat hamburg grape. Acta Agriculturae Boreali-Sinica 28: 155-162.

Thomas J (2014) Food additives - a growing global market: Leatherhead Food Research.

Tosun A, Khan S, Kim YS, Calin-Sanchez A, Hysenaj X \& Carbonell-Barrachina AA (2014) Essential oil composition and anti-inflammatory activity of Salvia officinalis L. (Lamiaceae) in Murin Macrophages. Tropical Journal of Pharmaceutical Research 13: 937-942. doi:10.4314/tjpr.v13i6.16

Vespermann KAC, Paulino BN, Barcelos MCS, Barcelos MCS, Pess AMG, Pastore GM \& Molina G (2017) Biotransformation of $\alpha$ - and $\beta$-pinene into 
flavor compounds. Applied Microbiology and Biotechnology 101: 1805-1817. doi:10.1007/ s00253-016-8066-7

Xu LP \& Yu FY (2015) Corolla structure and fragrance components in Styrax tonkinensis. Trees 29: 1127-1134. doi:10.1007/s00468-015-1193-4

Zhang Z, Guo S, Liu X \& Gao X (2015) Synergistic antitumor effect of $\alpha$-pinene and $\beta$-pinene with paclitaxel against non-small-cell lung car- cinoma (NSCLC). Drug Research 65: 214-218. doi:10.1055/s-0034-1377025

Zou JJ, Cai X, Zeng XL \& Wang CY (2017) Effect of light and temperature on the characteristic color compounds and aroma compounds in Osmanthus fragrans. Advances in Ornamental Horticulture of China 458-462. 